\title{
Metabolism During Asexual Sporulation in Rhizopus arrhizus (Fischer)
}

\author{
By GEORGE C. LAWLER*† AND DARRELL J. WEBER \\ Brigham Young University, Department of Botany, Provo, Utah 84602, U.S.A.
}

(Received 18 May 1979; revised 19 September 1979)

\begin{abstract}
The metabolism of Rhizopus arrhizus (Fischer) during growth and asexual sporulation was investigated. Aerobic respiration occurred during spore germination but changed to fermentation during the initial stages of growth. During the later stages of growth and sporulation, the respiration again became aerobic. The fermentative phase during the initial growth stage was a result of culture technique. Sporulation was induced by glucose exhaustion. Protein was the major endogenous substrate during sporulation. Lipid reserves decreased, but non-structural carbohydrate reserves remained unchanged. The fermentation acids, over half of which were taken up from the culture medium, were the major exogenous substrate during sporulation. Lactate was identified as one of two fermentation acids produced in significant quantities. On a weight consumed basis, the fermentation acids were the major substrates utilized during sporulation.
\end{abstract}

\section{INTRODUCTION}

Fungal spores have widely different ontogenies (Smith, 1978), which suggests that the biochemical processes involved in their differentiation might also be different (Turian, 1974). The metabolism of conidiation has been extensively studied in Neurospora crassa (Turian \& Bianchi, 1972; Turian, 1978) and Aspergillus niger (Smith \& Galbraith, 1971; Smith, 1978). The nature of the nitrogen source was found to be critical in relation to sporulation. In both of these fungi, ammonium was generally inhibitory to conidiation whereas nitrate was not (Turian, 1964; Galbraith \& Smith, 1969). Rhizopus spp. normally cannot utilize nitrate as a nitrogen source (Foster, 1949) but produce abundant sporangiospores on media with ammonium as the nitrogen source. These observations suggest that the metabolism of sporulation in Rhizopus spp. differs from that observed in Neurospora and Aspergillus spp.

Sporulation in fungal cultures generally occurs after a period of rapid growth and nutrient depletion (Smith \& Galbraith, 1971; Smith, 1978). The developmental phase of the culture during which sporulation generally takes place has been termed the idiophase as opposed to the trophophase for the period of rapid growth (Bu'lock et al., 1965; Nover \& Luckner, 1974). The metabolism of the idiophase is qualitatively and quantitatively different from that of the trophophase (Bu'lock et al., 1965).

In a previous paper (Lawler \& Weber, 1977) a method for achieving synchronous sporulation during idiophase development in surface cultures of Rhizopus arrhizus was described. The purpose of the present investigation was to follow the basic metabolism of $R$. arrhizus through idiophase sporulation.

$\dagger$ Present address: University of New Orleans, Lakefront, Louisiana, U.S.A. 


\section{METHODS}

Organism and culture conditions. Rhizopus arrhizus (Fischer) strain R-80 was grown on a modified Fothergill \& Yeoman's (1975) medium as previously described (Lawler \& Weber, 1977). Growth, sporulation and $\mathrm{CO}_{2}$ production were determined using the methods of Lawler \& Weber (1977).

Medium fractionation. Glucose and the fermentation acids were isolated from the growth medium by ion exchange chromatography (Amberlite CG-120, mesh 100/200, $0.9 \times 2.0 \mathrm{~cm}$ column). Analyses indicated that the glucose and fermentation acids were eluted by the first $25 \mathrm{ml}$ of $0 \cdot 1 \mathrm{M}-\mathrm{HCl}$.

Glucose analysis. The glucose content of the medium was determined by gas chromatographic analysis of the glucose fraction obtained by ion exchange chromatography. Glucose and the internal standard, xylose, were converted to methoxime-trimethylsilyl ether (MO-TMS) derivatives. A mixture of $100 \mu 1$ glucose solution and $100 \mu 1$ xylose standard solution $\left(5 \mathrm{mg} \mathrm{ml}^{-1}\right)$ was taken to dryness at $46{ }^{\circ} \mathrm{C}$ under a stream of purified $\mathrm{N}_{2}$ and $1 \mathrm{ml}$ methoxyamine. $\mathrm{HCl}$ (Regis Chemical Co., Morton Grove, Ill., U.S.A.) in gas chromatographic grade pyridine $\left(6 \mathrm{mg} \mathrm{ml}^{-1}\right)$ was added. This solution was heated to $76 \mathrm{C}$ for $0.5 \mathrm{~h}$ and then taken to dryness. Then $200 \mu \mathrm{l} 1 \%$ trimethylchlorosilane in bis(trimethylsilyl)trifluoroacetamide (BSTFA) (Regis Chemical Co.) was added and the solution was allowed to stand at room temperature for $3 \mathrm{~h}$ before being injected into the gas chromatograph. The MO-TMS derivatives of glucose and xylose gave separate symmetrical peaks on gas chromatographic analysis. A standard curve was prepared and used to determine glucose concentrations from the ratio of glucose MO-TMS to xylose MO-TMS (peak areas).

Fermentation acid analysis. Fermentation acids in the culture medium were identified and quantified by gas chromatographic analyses of the fermentation acid fraction of the medium. The fermentation acids were prepared as MO-TMS derivatives and also as trimethylsilyl ether-trimethylsilyl ester (TMS ether-TMS ester) derivatives. A $100 \mu \mathrm{l}$ sample of the fermentation acid fraction was taken to dryness at $46^{\circ} \mathrm{C}$ under a stream of purified $\mathrm{N}_{2}$ and the MO-TMS derivatives were formed by the procedure described by Horning et al. (1968). The TMS ether-TMS ester derivatives were formed by adding $200 \mu \mathrm{l}$ BSTFA to the residue of a dried $100 \mu \mathrm{l}$ sample of the fermentation acid fraction and allowing it to stand at room temperature for $3 \mathrm{~h}$ prior to injection. External quantitative standards were used to quantify the fermentation acids, which were run as TMS ether-TMS ester derivatives. Succinate (Sigma) was used to quantify the unknown gas chromatographic peak 2 .

Ethanol analysis. The ethanol content of the medium was determined by a direct injection gas chromatographic method (Jain, 1971). Acetone was used as the internal standard.

Carbohydrate determination. The total non-structural carbohydrate content of the freeze-dried mycelium was estimated by two analytical methods. Nelson's assay (Nelson, 1944) was used to determine the free reducing groups in carbohydrates and the total non-structural carbohydrates were estimated by the anthrone assay (Bailey, 1958).

Total lipids. Total lipids were isolated by a modification of the procedure developed by Bligh \& Dyer (1959). Lyophilized mycelium (approx. $300 \mathrm{mg}$ ) was extracted with $26.6 \mathrm{ml}$ chloroform/methanol/water $(1: 2: 0 \cdot 8$, by vol.) for $2 \mathrm{~min}$ in a Sorvall Omni-Mixer set at maximum speed. The resulting suspension was centrifuged for $30 \mathrm{~min}$ at $30000 \mathrm{~g}$ and the supernatant was retained. The pellet was re-extracted in the same manner and the supernatant solutions were combined. The chloroform/methanol/water ratio was then brought to $2: 2: 1 \cdot 8$ (by vol.) by adding the required amounts of chloroform and water to the combined supernatant solutions. The resulting two-layered system was thoroughly mixed and then centrifuged at $30000 \mathrm{~g}$ for $10 \mathrm{~min}$ to break up the emulsion that was formed by mixing the two phases. This resulted in a two-layered system with a white fluff at the interphase. A similar fluff layer was described by Folch et al. (1951) in the lipid extract of brain tissue and identified as proteolipid (Folch \& Lees, 1951). The fluff present in the lipid extract of $R$. arrhizus was subsequently treated as proteolipid. The upper water/methanol layer was removed and methanol was added to the chloroform/fluff fraction until the fluff went into solution. The protein moiety of the proteolipids was rendered insoluble in hot chloroform/methanol $(2: 1, \mathrm{v} / \mathrm{v})$ by taking a fluff solution to dryness at $46^{\circ} \mathrm{C}$ under a stream of purified $\mathrm{N}_{2}$ (Folch et al., 1951). The lipids were then dried in a vacuum desiccator overnight. After drying, the lipids were taken up in hot chloroform/ methanol $(2: 1, \mathrm{v} / \mathrm{v})$ and the mixture was filtered through Whatman no. 1 filter paper to remove insoluble particulate matter. The filtrate was collected in a tared beaker, taken to dryness, and weighed to determine total lipids.

Total proteins. Total proteins and nucleic acids were extracted by a procedure modified from that described by Nguyen \& Paquin (1971). The whole procedure was carried out at $4{ }^{\circ} \mathrm{C}$ and the extraction solution was phenol/acetic acid/water (PAW; 1:1:1, by vol.). Mycelium from a single culture (approx. $100 \mathrm{mg}$ ) and $20 \mathrm{ml}$ PAW were placed in a $50 \mathrm{ml}$ container and mixed (Sorvall Omni-Mixer, speed 9, 5 min) while being cooled in an ice bath. The resulting suspension was centrifuged at $30000 \mathrm{~g}$ for $10 \mathrm{~min}$ and the supernatant was retained. The pellet was re-extracted with $20 \mathrm{ml}$ PAW for $8 \mathrm{~h}$ with constant agitation and then further re- 
Table 1. Gas chromatography conditions for analyses of glucose, fermentation acids and ethanol

\author{
Analysis \\ Glucose \\ Column description \\ Column: $6 \mathrm{ft} \times 4 \mathrm{~mm}$ (i.d.) glass \\ Packing: $3 \%$ SE-30* on Gas Chrom Q* \\ $100 / 180$ mesh
}

Fermentation acids

Column: $6 \mathrm{ft} \times 4 \mathrm{~mm}$ (i.d.) glass

Packing: $3 \%$ SE-30 on Gas Chrom Q $100 / 180$ mesh

Ethanol

\author{
Column: $6 \mathrm{ft} \times 0.25$ in (o.d.) stainless steel \\ Packing: $30 \%$ Carbowax 20-M* on Gas \\ Chrom Q 100/180 mesh
}

Gas chromatography conditions

Oven temp.: 150 to $170{ }^{\circ} \mathrm{C}$, $2{ }^{\circ} \mathrm{C}$ min $^{-1}$ after 25 min hold Detector temp.: $230^{\circ} \mathrm{C}$ Injection port temp.: $230^{\circ} \mathrm{C}$ $\mathrm{N}_{2}$ flow rate: $32.5 \mathrm{ml} \mathrm{min}^{-1}$

Oven temp.: 50 to $200{ }^{\circ} \mathrm{C}$, $1^{\circ} \mathrm{C} \mathrm{m^{-1 }}$ after 10 min hold + Detector temp.: $200^{\circ} \mathrm{C}$ Injection port temp. : $200{ }^{\circ} \mathrm{C}$

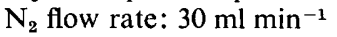

Oven temp.: $100^{\circ} \mathrm{C}$

Detector temp.: $130{ }^{\circ} \mathrm{C}$

Injection port temp.: $130^{\circ} \mathrm{C}$

$\mathrm{N}_{2}$ flow rate: $30 \mathrm{ml} \mathrm{min}^{-1}$

* From Applied Science Laboratories.

$\uparrow$ Initial hold of $25 \mathrm{~min}$ for MO-TMS derivatives.

extracted for $3 \mathrm{~h}$ under the same conditions. The three supernatants were then combined. Small amounts of particulate matter were removed from the combined supernatant solutions by centrifuging at $30000 \mathrm{~g}$ for $1 \mathrm{~h}$. The supernatant solution from this centrifugation was removed and an equal volume of $10 \%(\mathrm{w} / \mathrm{v})$ trichloroacetic acid (TCA) solution was added to it. The resulting solution was kept under constant agitation and the proteins and nucleic acids were allowed to precipitate overnight. The TCA precipitate was collected by filtration through a tared Millipore Solveinert filter (mean pore size $0.25 \mu \mathrm{m}$ ). The filter and TCA precipitate were lyophilized overnight and reweighed to determine the dry weight of the total TCA precipitate. To extract the nucleic acids from the total TCA precipitate, it was immersed in $5 \%(w / v)$ TCA and heated to $60 \pm 1{ }^{\circ} \mathrm{C}$ for $15 \mathrm{~min}$ (Schneider, 1945). The suspension was allowed to cool to room temperature $\left(24^{\circ} \mathrm{C}\right)$ and the TCA precipitate insoluble in hot TCA was collected by filtration through a tared Millipore Solveinert filter. The filter and TCA precipitate were lyophilized overnight and weighed. The dry weight of the TCA precipitate that was insoluble in hot TCA was used as an estimate of total proteins. Proteins in the medium were estimated by the Lowry method.

Spore analyses. Spores were harvested from cultures grown for $48 \mathrm{~h}$ on potato dextrose agar. The Petri dishes were flooded with deionized, distilled water and the spores were collected from the resulting suspension by centrifuging at $10000 \mathrm{~g}$ for $10 \mathrm{~min}$. The spores were washed three times by resuspending them in deionized, distilled water and centrifuging, and they were then lyophilized for $24 \mathrm{~h}$ prior to extraction. Total lipids and total proteins were determined, as described above, for the spores with and without prior fracturing of the spore coat. Total nucleic acids were measured as the weight loss of the total TCA precipitate after extraction with hot TCA solution. The spore coats were fractured by grinding the spores with 3 to 4 measures of alumina, type 305 (Sigma) in a mortar and pestle. Enough of the appropriate extraction solution was added to make a thick slurry, which was ground for $30 \mathrm{~min}$ with a pestle fitted to a variable speed electric drill. This procedure fractured 90 to $95 \%$ of the spores. Spores that were extracted without fracturing were treated in the same way as mycelium in the extraction procedures described above.

Gas chromatographic and mass spectrometric analysis. Gas chromatographic analyses were carried out on a series 7300 Packard gas chromatograph equipped with a hydrogen flame detector. Peak areas, calculated by the height $x$ width at half-height method, were used to quantify eluted compounds. Retention times, measured from the leading edge of the solvent front, were used to identify unknown fermentation acids. Qualitative standards used were lactic, fumaric, succinic and maleic acids. Column descriptions and gas chromatographic conditions used in this investigation are listed in Table 1. The TMS compounds were analysed on an LKB 9000 GC-mass spectrometer connected to a PDP8e mini-computer.

Morphological observations. Observations of spore germination and the initial stages of growth, up to $12 \mathrm{~h}$ after inoculation, were made at $100 \times$ and $400 \times$ magnification. Cultures used for these observations were grown in $100 \times 20 \mathrm{~mm}$ Petri dishes. After $12 \mathrm{~h}$, unaided observations of growth and sporulation were made on experimental cultures grown in $500 \mathrm{ml}$ Erlenmeyer flasks. 


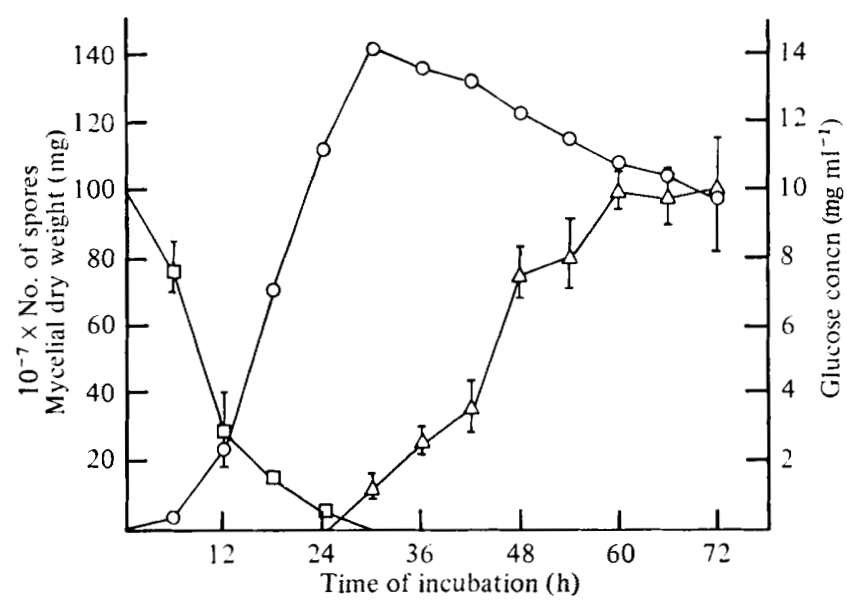

Fig. 1. Relationships between growth, sporulation and glucose content of the medium of cultures of Rhizopus arrhizus. $O$, Mycelial dry weight (mean of 8 to 11 replicates \pm s.D.); $\Delta$, number of spores per culture (mean of 4 replicates \pm s.D.); $\square$, residual glucose concentration (mean of 3 replicates \pm S.D., except for the $18 \mathrm{~h}$ value which is the mean of 2 replicates).



Fig. 2. Relationship between $\mathrm{CO}_{2}$ production, glucose utilization, ethanol production and $\mathrm{pH}$ of the medium of cultures of Rhizopus arrhizus. $\mathbf{\square}, \mathrm{CO}_{2}$ production; $\square$, residual glucose; $O$, ethanol production;, $\mathrm{pH}$ of the medium. Each value is the mean of 3 replicates, except the residual glucose value at $18 \mathrm{~h}$ which is the mean of 2 replicates.

\section{RESULTS}

Growth, sporulation and glucose concentration. Measurements of growth, sporulation and glucose concentration of the medium were made every $6 \mathrm{~h}$ over a $72 \mathrm{~h}$ period (Fig. 1). The lag phase of growth lasted $6 \mathrm{~h}$, followed by the linear growth phase; then growth stopped at around $30 \mathrm{~h}$ and there was a steady decline in mycelial dry weight up to $72 \mathrm{~h}$. The mycelial dry weight decreased by $47.4 \mathrm{mg}$ during the decline phase. The first mature sporangia were detected at $30 \mathrm{~h}$. Sporulation occurred at an almost constant rate from $30 \mathrm{~h}$ until it stopped at $60 \mathrm{~h}$. The number of spores per culture did not increase after 60 to $72 \mathrm{~h}$. The glucose concentration of the medium decreased significantly during the first $6 \mathrm{~h}$ after inoculation and continued to decline rapidly from 6 to $24 \mathrm{~h}$. Complete depletion of glucose from the medium, which occurred between 24 and $30 \mathrm{~h}$, coincided with the cessation of growth and the onset of sporulation. 


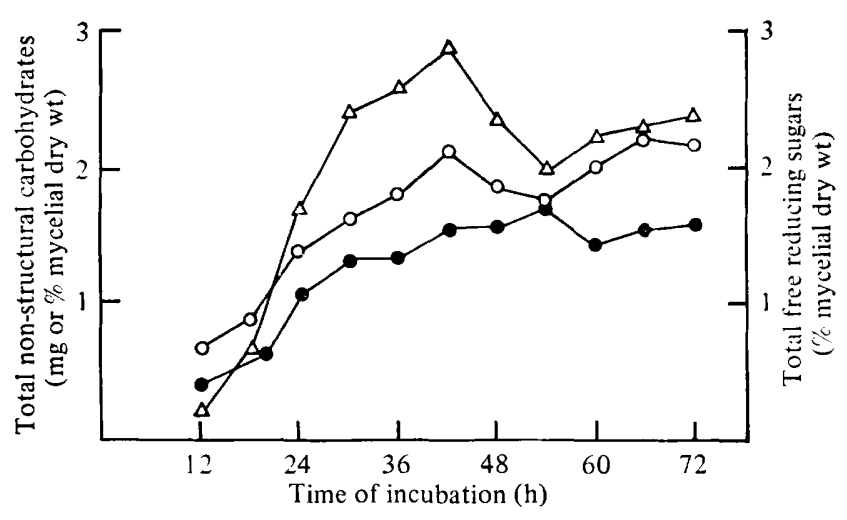

Fig. 3. Changes in total non-structural carbohydrates during growth and sporulation of Rhizopus arrhizus. O, Total free reducing sugars as a percentage of mycelial dry weight; $O$, total nonstructural carbohydrates per culture; $\triangle$, total non-structural carbohydrates as a percentage of mycelial dry weight. Each total non-structural carbohydrate value is the mean of 3 replicates.

$\mathrm{CO}_{2}$ production, $p \mathrm{H}$ and ethanol concentration. $\mathrm{CO}_{2}$ production was continuously monitored over the entire $72 \mathrm{~h}$ culture period. The results (Fig. 2) indicate that $\mathrm{CO}_{2}$ production occurred in three distinct phases: the first was associated with germination and the early stages of growth, the second occurred during the rapid period of growth and the third occurred during sporulation. The $\mathrm{pH}$ and ethanol content of the medium were determined at $6 \mathrm{~h}$ intervals. Only a trace of ethanol was detected in the medium at $6 \mathrm{~h}$. There was then a rapid increase in ethanol concentration which coincided with increased $\mathrm{CO}_{2}$ production up to $17 \mathrm{~h}$ after inoculation. This was followed by an almost equally rapid decrease in ethanol concentration from 18 to $30 \mathrm{~h}$. Ethanol was not detected in the medium after $30 \mathrm{~h}$. The $\mathrm{pH}$ of the medium remained relatively constant during the first few hours of growth, showing only a slight decrease from 6 to $12 \mathrm{~h}$. From 12 to $18 \mathrm{~h}$ the pH dropped rapidly from $6 \cdot 1$ to 3.6 and remained at that level until $30 \mathrm{~h}$. The $\mathrm{pH}$ gradually increased during the third phase of $\mathrm{CO}_{2}$ production until it reached 5.9 at $72 \mathrm{~h}$.

Carbohydrate content of mycelium. The total non-structural carbohydrate content of the mycelium was determined at $6 \mathrm{~h}$ intervals for $72 \mathrm{~h}$ (Fig. 3). Total non-structural carbohydrates per culture increased steadily with increasing dry weight up to $30 \mathrm{~h}$ after inoculation and then remained relatively constant until $72 \mathrm{~h}$. A slight peak occurred at $42 \mathrm{~h}$, midway in the sporulation period. Total non-structural carbohydrates as a percentage of mycelial dry weight showed a fairly steady increase from $12 \mathrm{~h}$ after inoculation until $72 \mathrm{~h}$, but again there was a slight peak at $42 \mathrm{~h}$ after inoculation.

Changes in the levels of total free reducing sugars, although detected in lower overall concentrations than total non-structural carbohydrates, followed the same general patterns as observed for the total non-structural carbohydrates on both a per culture basis and as a percentage of mycelial dry weight. That is, total free reducing sugars per culture increased with increasing mycelial dry weight to $30 \mathrm{~h}$ after inoculation and remained relatively unchanged up to $72 \mathrm{~h}$. Total free reducing sugars as a percentage of mycelial dry weight showed a general trend of increasing concentrations until at least $54 \mathrm{~h}$ after inoculation (Fig. 3).

Total lipids. The total lipid content of the mycelium was determined at $6 \mathrm{~h}$ intervals for $72 \mathrm{~h}$ (Fig. 4). Total lipids per culture increased with increasing mycelial dry weight up to the highest recorded values for both, which occurred at $36 \mathrm{~h}$. After this time, total lipids per culture and mycelial dry weight decreased as sporulation occurred. The mean decrease in total lipids per culture during sporulation $(36$ to $60 \mathrm{~h}$ ) was $7.0 \mathrm{mg}$, which represented 


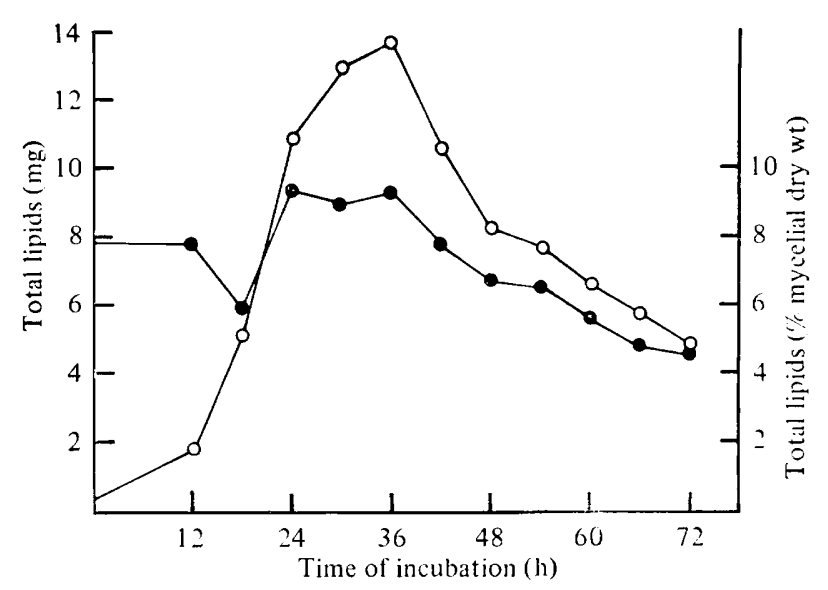

Fig. 4. Changes in total lipids during growth and sporulation of Rhizopus arrhizus. $\bigcirc$, Total lipids per culture; - total lipids as a percentage of mycelial dry weight. Each total lipid value is the mean of 2 replicates.

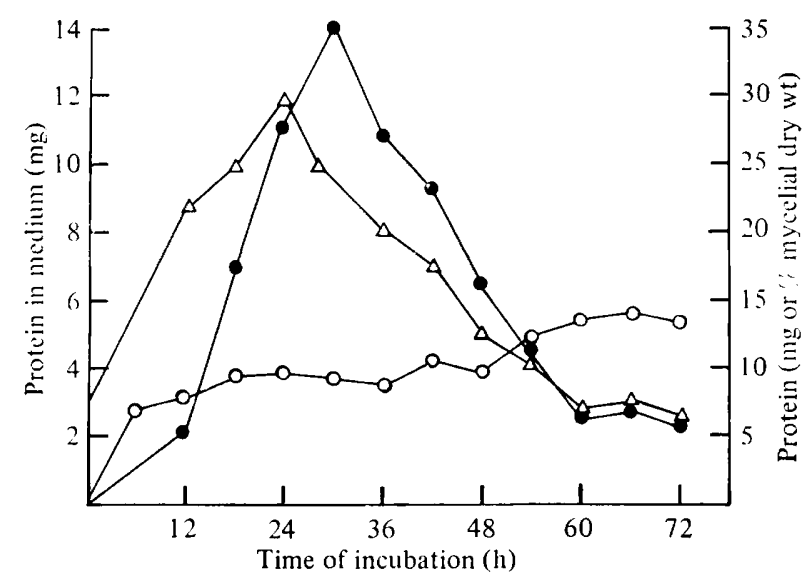

Fig. 5. Changes in protein content during growth and sporulation of Rhizopus arrhizus. $\bigcirc$, Protein in the culture medium (mean of 3 replicates); 0 , total protein per culture (mean of 2 replicates); $\triangle$, total protein as a percentage of mycelial dry weight (mean of 2 replicates).

$20 \cdot 2 \%$ of the loss in mycelial dry weight. Total lipids as a percentage of mycelial dry weight reached a peak between 24 and $36 \mathrm{~h}$ and then steadily declined during sporulation. Rhizopus arrhizus consumed $51.8 \%$ of its lipid reserves during sporulation.

Total proteins. Total mycelial protein was determined every $6 \mathrm{~h}$ for $72 \mathrm{~h}$ (Fig. 5). Total protein per culture increased with mycelial dry weight up to $30 \mathrm{~h}$ after inoculation. The peak occurred at the maximum mycelial dry weight. After $30 \mathrm{~h}$, total protein per culture decreased as mycelial dry weight decreased and sporulation was occurring. From 30 to $60 \mathrm{~h}$, total protein per culture decreased $27.1 \mathrm{mg}$, which represented $67.7 \%$ of the loss in mycelial dry weight. Total proteins as a percentage of mycelial dry weight also increased with mycelial dry weight, but reached a maximum value at $24 \mathrm{~h}$, about $6 \mathrm{~h}$ before maximum mycelial dry weight. Total proteins as a percentage of mycelial dry weight also steadily decreased during sporulation $(24$ to $60 \mathrm{~h}$ ). No further reductions were observed after $60 \mathrm{~h}$. Rhizopus arrhizus consumed $77.4 \%$ of its endogenous protein during sporulation. A relatively large amount of protein was detected in the culture medium (Fig. 5). The protein concentration 
Table 2. Effects of fracturing the spore coat of $R$. arrhizus spores on extraction of total lipids, and total proteins and nucleic acids

\begin{tabular}{|c|c|c|c|}
\hline \multirow[b]{2}{*}{ Extract } & \multicolumn{2}{|c|}{ Extract content ( $\%$ spore dry wt) } & \multirow{2}{*}{$\frac{\text { Unfractured }}{\text { Fractured }} \begin{array}{c}(\%) \\
(\%)\end{array}$} \\
\hline & $\begin{array}{l}\text { Unfractured } \\
\text { spores }\end{array}$ & $\begin{array}{c}\text { Fractured } \\
\text { spores* }\end{array}$ & \\
\hline Total lipids & $3 \cdot 4$ & $8 \cdot 1 \pm 0.7 \dagger$ & $42 \cdot 0$ \\
\hline Total TCA precipitate & $2 \cdot 7$ & $10 \cdot 2 \pm 2 \cdot 8$ & $26 \cdot 5$ \\
\hline Proteins & 一 & $4 \cdot 5 \pm 1 \cdot 2$ & - \\
\hline Nucleic acids & 一 & $5 \cdot 7 \pm 1 \cdot 5$ & - \\
\hline
\end{tabular}

Table 3. Changes in medium fermentation acid content of cultures of $R$. arrhizus indicating approximate uptake of fermentation acids from 24 to $60 \mathrm{~h}$ after inoculation

\begin{tabular}{|c|c|c|c|}
\hline \multirow[b]{2}{*}{ Time (h) } & \multicolumn{3}{|c|}{ Fermentation acid content of medium (mg) } \\
\hline & Lactate* & Peak 2* & Total \\
\hline $\begin{array}{l}24 \\
60\end{array}$ & $\begin{array}{l}45 \cdot 5 \\
15 \cdot 2\end{array}$ & $\begin{array}{l}47 \cdot 0 \\
25 \cdot 6\end{array}$ & $\begin{array}{l}92 \cdot 5 \\
40 \cdot 8\end{array}$ \\
\hline Uptake $(\%)$ & $66 \cdot 5$ & $45 \cdot 5$ & $55 \cdot 9$ \\
\hline
\end{tabular}

increased slightly from 6 to $18 \mathrm{~h}$ and then remained fairly constant to $36 \mathrm{~h}$. There was a second increase in protein concentration from 36 to $60 \mathrm{~h}$. The highest recorded reading which occurred at $66 \mathrm{~h}$, amounted to $5.6 \mathrm{mg}$ protein per culture.

Total lipids, total proteins and nucleic acids of spores. Fracturing of the spores was necessary for maximum extraction of lipids, proteins and nucleic acids (Table 2). Total lipids in the fractured spores accounted for $8.0 \%$ of the spore dry weight, total proteins represented $4.5 \%$ and nucleic acids $5.7 \%$.

Fermentation acids. There were no significant differences between the gas chromatographic analyses of the fermentation acids prepared as MO-TMS derivatives and TMS ether-TMS ester derivatives. Each derivative preparation yielded gas chromatograms with two major peaks. The retention time for the first peak $(43.3 \mathrm{~min})$ was very close to that of TMSlactate $(42.9 \mathrm{~min})$ and the mass spectrogram was identical to the TMS-lactate standard. The retention time of the second peak $(75.2 \mathrm{~min})$ was the same as that of TMS-maleate. However, the mass spectrum of the compound was not identical to the spectrum of TMSmaleate. The total fermentation acid content of the medium was reduced by approximately $56 \%$ between 24 and $60 \mathrm{~h}$ after inoculation (Table 3).

Morphological observations. At $6 \mathrm{~h}$ after inoculation germ tubes of varying lengths were visible on different spores, indicating that germination was not synchronous. The germ tube extended outward along the surface of the medium for a distance equal to 3 to 4 times the diameter of the spore (approx. $30 \mu \mathrm{m}$ ) and then turned into the medium. At $12 \mathrm{~h}$ after inoculation a thin mycelial pad appeared to cover the surface of the medium, but closer inspection indicated that the pad was actually subsurface. At $18 \mathrm{~h}$ after inoculation the aerial portion of the culture was well developed. Heavy growth was apparent by $24 \mathrm{~h}$, but no developing sporangia were observed. The first mature sporangia were detected at $30 \mathrm{~h}$. 


\section{DISCUSSION}

Depletion of the carbon or nitrogen sources from the medium are the two most important nutrient inducements to sporulation (Smith \& Galbraith, 1971; Smith, 1978). In relating metabolic activities to morphological changes induced by nutrient depletion, it is important to identify the limiting nutrient which induces the morphological response.

Growth of Rhizopus stolonifer in standard Fothergill \& Yeoman's medium was ultimately inhibited by nitrogen starvation (Fothergill \& Yeoman, 1957). They demonstrated that as the $\mathrm{pH}$ of the medium fell to $\mathrm{pH}$ 2, ammonium uptake from the medium was inhibited and growth stopped in an apparent excess of nutrients. In the present study the glucose content of the Fothergill \& Yeoman medium was reduced from 40 to $10 \mathrm{~g} \mathrm{l}^{-1}$ and sporulation was induced in $R$. arrhizus by glucose exhaustion. The fact that the $\mathrm{pH}$ of the medium did not drop below pH 3.4 indicates that nitrogen starvation was not a factor in the induction of sporulation.

Respiration in cultures of $R$. arrhizus showed three distinct phases: germination, growth (trophophase) and sporulation (idiophase). Spores of $R$. arrhizus require oxygen to germinate (Ekundayo \& Carlile, 1964; Bussel et al., 1970). At $8.5 \mathrm{~h}$ after inoculation respiration of the cultures shifted from predominantly aerobic to predominantly fermentative as indicated by the significant increase in the ethanol content of the medium. Fermentative growth lasted only a short time, but due to the inefficiency of the fermentation process much glucose was consumed and $\mathrm{CO}_{2}$ liberated. A substantial amount of aerial mycelium developed between 12 and $18 \mathrm{~h}$ and aerobic respiration increased. Oxygen has been shown to generally enhance the production of fermentation acids in Rhizopus sp. (Foster, 1949), and a period of oxidative respiration was required for induction of the ability to produce lactic acid in Rhizopus oryzae (Hongo \& Uyeda, 1972). Surface growth was heavy at $24 \mathrm{~h}$ and ethanol disappeared from the medium at a greater rate than it was produced, indicating that respiration of the cultures was predominantly aerobic by $24 \mathrm{~h}$.

As glucose and ethanol were depleted from the medium the respiration rate fell and idiophase sporulation was induced. Idiophase is often induced by nutrient depletion and its course can be followed by shifts in respiration, which are indicative of metabolic shifts taking place within the organism (Demain, 1968). In this experiment the rise in $\mathrm{pH}$ during the 30 to $72 \mathrm{~h}$ period was almost reciprocal to the $\mathrm{CO}_{2}$ production pattern during idiophase sporulation. This suggests that the fermentation acids taken up from the medium $(55.9 \%$ from 24 to $60 \mathrm{~h}$ ) are used in aerobic respiration to furnish energy for the sporulation process. Croes (1967) reported that acetate taken up by sporulating yeast cells was metabolized to furnish energy for the conversion of endogenous reserves into ascospores. Based primarily on his work with $N$. crassa, Turian (1978) proposed that sporulation is a morphological expression of the Pasteur effect. This does not appear to be the case in R. arrhizus. Fermentation, which is probably a consequence of the culture method, was the primary means of respiration for only about $8 \mathrm{~h}$ early in the growth phase. Hawker \& Hepden (1962) reported that sexual sporulation in Rhizopus sexualis and some other fungi occurred after a period of intense respiration. The $\mathrm{CO}_{2}$ evolution pattern that they presented was similar to the one observed for R. arrhizus.

Wright (1973) observed that differentiation in micro-organisms takes place at the expense of endogenous reserves in systems that are to a greater or lesser extent isolated from their environment. During the period 24 to $60 \mathrm{~h}$ the spore dry weight per culture increased to $33.3 \%$ of the culture dry weight at $60 \mathrm{~h}$. This indicates that during sporulation both anabolic and catabolic processes are taking place. The fact that fermentation acids are also taken up from the medium during the same period indicates that $R$. arrhizus is not completely isolated from its environment during sporulation and that fermentation acids are involved in the metabolism of sporulation. Total lipids and total proteins decreased in absolute 
concentration per culture and as a percentage of the mycelial dry weight during sporulation, while the concentration of total non-structural carbohydrates and total free reducing sugar remained relatively constant on the per culture basis and generally increased as a percentage of the mycelial dry weight during the same period. Surprisingly, proteins appear to be an important source of endogenous substrates during sporulation in $R$. arrhizus. The measured decrease in total proteins from 30 to $60 \mathrm{~h}$ accounts for $67.7 \%$ of the loss in mycelial dry weight observed in the cultures grown for protein analysis.

Once differentiating spores develop spore coats their cytoplasm is no longer available to the culture for use in the sporulation process. Calculations based on the percentage of protein in the total spore dry weight at the end of sporulation $(60 \mathrm{~h})$ indicated that $1.6 \mathrm{mg}$ protein was incorporated in the spores during the sporulation process. Since extracellular enzymes have been described for $R$. arrhizus (Benzonana, 1974; Marshall, 1973), it was also possible that the decrease in mycelial proteins was due to the excretion of proteins into the medium. The medium protein content increased by $1.8 \mathrm{mg}$ per culture from 30 to $60 \mathrm{~h}$. From the above information and taking into account the amount of protein extracted from the unfractured spores, it was calculated that $12.7 \%$ of the protein lost during sporulation could be accounted for by means other than degradation. After adjusting for the protein lost to the spores and medium, protein degradation still accounted for $58.2 \%$ of the decrease in culture dry weight. Simultaneous degradation and synthesis has been shown to occur during sporulation in other fungi (Timberlake et al., 1973; MaGee \& Hopper, 1974); Stokes \& Gunness (1946) reported that only $50 \%$ of the protein present in the vegetative mycelium remained after conidiation in $A$. niger.

The lipid results presented verify the finding of Weete et al. (1973) which indicated that total lipids, expressed as a percentage of dry weight, decrease during sporulation in $R$. arrhizus. Lipids could be utilized as a source of energy or substrates for biosynthesis during sporulation.

The concentrations of total non-structural carbohydrates and total free reducing sugars on a per culture basis remained relatively constant during the sporulation period, even though the dry weight per culture was decreasing. As expected from the preceding observations total non-structural carbohydrates and total free reducing sugars when expressed as a percentage of the mycelial dry weight showed a slight increase during the same period. The fact that total non-structural carbohydrates did not decrease during sporulation was unexpected since the concentration of trehalose was observed to decrease rapidly after conidiation of $N$. crassa (Hanks \& Sussman, 1969).

The measured decreases in total proteins and total lipids can account for about 66 to $88 \%$ of the total per culture weight loss during sporulation. The higher percentage was derived from the unadjusted total protein and total lipid weight loss figures. The unaccounted for per culture weight loss is probably due to error inherent in the relatively insensitive analytical techniques utilized in this study. Since nucleic acids were not monitored, however, the possibility of a significant decrease of mycelial nucleic acid content cannot be ruled out.

In cultures of $R$. arrhizus, the fermentation acids can be considered as exogenous substrates that are utilized during idiophase sporulation. On a weight basis, they make a contribution to the metabolism of sporulation that is greater than that made by the endogenous reserves. Lactate was the major exogenous substrate during sporulation in $R$. arrhizus and has been shown to serve a similar function in other Rhizopus species.

We wish to express appreciation to the Research Division, Brigham Young University for partly supporting this research and to Connie Swenson for technical help. 


\section{REFERENCES}

BAILEY, R. W. (1958). The reaction of pentoses with anthrone. Biochemical Journal 68, 669-672.

Benzonana, G. (1974). Some properties of an exocellular lipase from Rhizopus arrhizus. Lipids 9, 166-172.

Bligh, E. G. \& DYeR, W. J. (1959). A rapid method of total lipid extraction and purification. Canadian Journal of Biochemistry 37, 911-917.

Bu'lock, J. D., Hamilton, D., Hulme, M. A., Powell, A. J., Smalley, H. M., ShePherd, D. \& Smith, G. N. (1965). Metabolic development and secondary biosynthesis in Penicillium utricae. Canadian Journal of Microbiology 11, 765-778.

Bussel, J., Sommer, N. F. \& Kosuge, T. (1970). Effect of anaerobiosis upon germination and survival of Rhizopus stolonifer sporangiospores. Phytopathology 59, 946-952.

Croes, A. F. (1967). Induction of meiosis in yeast. II. Metabolic factors leading to meiosis. Planta 76, 227-237.

Demain, A. L. (1968). Regulatory mechanisms and the industrial production of microbial metabolites. Lloydia 31, 395-448.

Ekundayo, J. A. \& Carlile, M. J. (1964). The germination of sporangiospores of Rhizopus arrhizus: spore swelling and germ-tube emergence. Journal of General Microbiology 35, 261-269.

FolCh, J. \& LeEs, M. (1951). Proteolipids, a new type of tissue lipoprotein: their isolation from brain. Journal of Biological Chemistry 191, 807-817.

Folch, J., Ascoli, I., Lees, M., Meath, J. A. \& Lebaron, E. N. (1951). Preparation of lipid extracts from brain tissues. Journal of Biological Chemistry 191, 833-841.

Foster, J. W. (1949). Chemical Activities of Fungi. New York: Academic Press.

Fothergill, P. G. \& Yeoman, M. M. (1957). The mineral nutrition of Rhizopus stolonifer. Journal of General Microbiology 17, 631-639.

Galbraith, J. C. \& Smith, J. E. (1969). Sporulation of Aspergillus niger in submerged liquid culture. Journal of General Microbiology 59, 31-45.

Hanks, D. L. \& Sussman, A. S. (1969). The relation between growth, conidiation and trehalase activity in Neurospora crassa. American Journal of Botany 56, 1152-1159.

HAWKer, L. E. \& HePdeN, P. M. (1962). Sporulation in Rhizopus sexualis and some other fungi following a period of intense respiration. Annals of Botany 27, 619-632.

Hongo, M. \& UyedA, M. (1972). Studies on oxidation-reduction potentials (ORP) of microbial cultures. IV. Lactic acid fermentation by Rhizopus G-36 (2). Agricultural and Biological Chemistry 36, 279-284.

Horning, M. G., Boucher, E. A., Moss, A. M. \& HoRning, E. C. (1968). Gas chromatographic study of derivatives of acids of the Krebs cycle and related compounds. Analytical Letters 1, 713-723.

JAIN, C. N. (1971). Direct blood-injection method for gas chromatographic determination of alcohols and other volatile compounds. Clinical Chemistry 17, 82-85.

LAWLer, G. C. \& Weber, D. J. (1977). Synchronous sporulation during idiophase development in surface cultures of Rhizopus arrhizus (Fischer). Canadian Journal of Microbiology 23, 1018-1025.

MaGee, P. T. \& Hopper, A. K. (1974). Protein synthesis in relation to sporulation and meiosis in yeast. Journal of Bacteriology 119, 952--960.

Marshall, J. J. (1973). Purification and some properties of Rhizopus arrhizus beta 1,3 glucanase. Biochemical Society Transactions 1, 445-452.

Nelson, N. (1944). A photometric adaption of the Somogyi method for the determination of glucose. Journal of Biological Chemistry 153, 375-380.

Nguyen, S. T. \& Paquin, R. (1971). Methodes d'estraction et de purification des acids amines libres et des proteins de tissues vegetaux. Journal of Chromatography 61, 349-351.

Nover, L. \& LuChner, M. L. (1974). Expression of secondary metabolism as part of the differentiation processes during the idiophase development of Penicillium cyclopium Westling. Biochemie und Physiologie der Pflanzen 166, 293-305.

SCHNEIDER, W. C. (1945). Phosphorus compounds in animal tissues. I. Extraction and estimation of desoxypentose nucleic acid and of pentose nucleic acid. Journal of Biological Chemistry 161, 293-303.

SMITH, J. (1978). Asexual sporulation in filamentous fungi. In The Filamentous Fungi, vol. 3, pp. 214 239. Edited by J. Smith \& D. Berry. New York: John Wiley.

Smith, J. E. \& Galbraith, J. L. (1971). Biochemical and physiological aspects of differentiation in the fungi. Advances in Microbial Physiology 5, 45-134.

Stokes, J. L. \& GuNNESS, M. (1946). The amino acid composition of micro-organisms. Journal of Bacteriology 52, 195-207.

Timberlake, W. E., McDowell, L., Cheney, J. \& Griffin, D. H. (1973). Protein synthesis during differentiation of sporangia in the water mold Achlya. Journal of Bacteriology 116, 67-73.

Turian, G. (1964). Synthetic conidiogenous media for Neurospora crassa. Nature, London 202, 1240.

Turian, G. (1974). Sporogenesis in fungi. Annual Review of Phytopathology 12, 129-137.

TURIAN, G. (1978). Sexual morphogenesis in the ascomycetes. In The Filamentous Fungi, vol. 3, pp. 315-333. Edited by J. Smith \& D. Berry. New York: John Wiley.

Turian, G. \& BIANCHI, D. E. (1972). Conidiation in Neurospora. Botanical Review 28, 118-154.

WeEte, J. D., Lawler, G. C. \& Laseter, J. L. (1973). Total lipid and sterol components of Rhizopus arrhizus: identification and metabolism. Archives of Biochemistry and Biophysics 155, 411-419.

Wright, B. E. (1973). Critical Variables in Differentiation (Concepts of Modern Biology Series), pp. 58-84. Englewood Cliffs, New Jersey: PrenticeHall. 